\title{
Mitigation of Suspendable Road Dust in a Subpolar, Oceanic Climate
}

\author{
Brian Charles Barr ${ }^{1}$, Hrund Ólöf Andradóttir ${ }^{2, *}$, Throstur Thorsteinsson 1,3 [i] and Sigurður Erlingsson ${ }^{2}$ \\ 1 Faculty of Earth Sciences, School of Engineering and Natural Sciences, University of Iceland, Sturlugata 7, \\ 102 Reykjavík, Iceland; bcb1@hi.is (B.C.B.); thorstur@hi.is (T.T.) \\ 2 Faculty of Civil and Environmental Engineering, School of Engineering and Natural Sciences, University of \\ Iceland, Hjardarhagi 2-6, 107 Reykjavík, Iceland; sigger@hi.is \\ 3 Faculty of Environment and Natural Resources, School of Engineering and Natural Sciences, University of \\ Iceland, Sturlugata 7, 102 Reykjavík, Iceland \\ * Correspondence: hrund@hi.is
}

Citation: Barr, B.C.; Andradóttir H.Ó.; Thorsteinsson, T.; Erlingsson, S. Mitigation of Suspendable Road Dust in a Subpolar, Oceanic Climate. Sustainability 2021, 13, 9607. https:// doi.org/10.3390/su13179607

Academic Editors: José Carlos

Magalhães Pires and

Álvaro Gómez-Losada

Received: 26 July 2021

Accepted: 22 August 2021

Published: 26 August 2021

Publisher's Note: MDPI stays neutral with regard to jurisdictional claims in published maps and institutional affiliations.

Copyright: (C) 2021 by the authors. Licensee MDPI, Basel, Switzerland. This article is an open access article distributed under the terms and conditions of the Creative Commons Attribution (CC BY) license (https:/ / creativecommons.org/licenses/by/ $4.0 /)$.

\begin{abstract}
Tire and road wear particles (TRWP) are a significant source of atmospheric particulate matter and microplastic loading to waterways. Road wear is exacerbated in cold climate by the widespread use of studded tires. The goal of this research was to assess the anthropogenic levers for suspendable road dust generation and climatic conditions governing the environmental fate of non-exhaust particles in a wet maritime winter climate. Sensitivity analyses were performed using the NORTRIP model for the Capital region of Reykjavík, Iceland $\left(64.1^{\circ} \mathrm{N}\right)$. Precipitation frequency (secondarily atmospheric relative humidity) governed the partitioning between atmospheric and waterborne $\mathrm{PM}_{10}$ particles (55\% and 45\%, respectively). Precipitation intensity, however, increased proportionally most the drainage to waterways via stormwater collection systems, albeit it only represented $5 \%$ of the total mass of dust generated in winter. A drastic reduction in the use of studded tires, from $46 \%$ to $15 \%$ during peak season, would be required to alleviate the number of ambient air quality exceedances. In order to achieve multifaceted goals of a climate resilient, resource efficient city, the most important mitigation action is to reduce overall traffic volume. Reducing traffic speed may help speed environmental outcomes.
\end{abstract}

Keywords: particulate matter; microplastics; non-exhaust emissions; NORTRIP

\section{Introduction}

Road infrastructure plays a significant role in sustainable cities. Besides enabling the transport of people and goods, roads must ideally be safe, economical, climate resilient, and non-compromising of the urban environment [1]. A key challenge to attaining these joint environmental, economic, and societal goals is the multifaceted pollution associated with the frictional contact between a moving vehicle and the road surface (Figure 1). Non-exhaust particles from tire-, road-, and break wear have been recognized as an important source of particulate matter pollution in the 2.5 to $10 \mu \mathrm{m}$ diameter range [2-8]. More recently, tire and bitumen asphalt road wear particles have emerged as a major microplastics (MP) source to the environment [9-11], and the largest MP contributor to aquatic environments [12], accounting for $5-10 \%$ of all plastics in the oceans, with country estimates ranging from $0.9 \%$ in The Netherlands to $32 \%$ in Norway [13]. Over 30\% of the coarse airborne tire and break wear particles $\left(\leq 10 \mu \mathrm{m}\right.$ diameter, $\left.\mathrm{PM}_{10}\right)$ is ultimately deposited in the world's oceans; a similar order of magnitude as direct and riverine transport [14]. The frictional contact between tire and road also generates noise pollution and pavement deterioration, which is influenced by climatic factors such as air temperature, solar radiation, and precipitation, each of which governs road wetness $[15,16]$. Fine particulate matter and traffic noise have been found as the first and second most important environmental causes of ill health in Western Europe [17]. A growing concern is that the smallest waterborne MP particles can accumulate in the cells and tissues of aquatic organisms and enter the food chain [18]. 


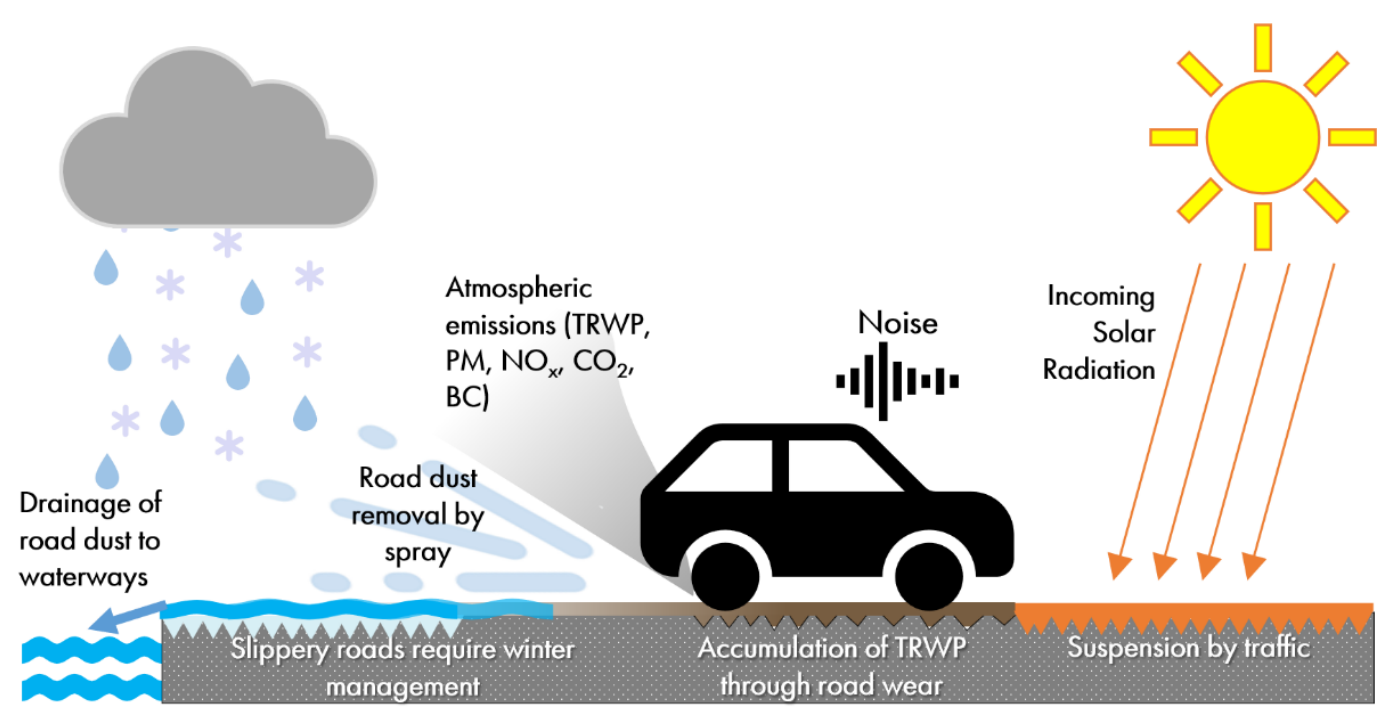

Figure 1. Road wear compromises the multifaceted goals of sustainable urban living, including safety, resource efficiency, amenities, and climate resilience.

Climatic conditions strongly influence the physical characteristics of pavements. Road safety and environmental problems are greatest near freezing air temperatures $\left( \pm 2{ }^{\circ} \mathrm{C}\right)$ [19], which exacerbate the use of studded tires and deicing agents for anti-skid protection [5,20-22]. Studded tires paired with high vehicle speed further increases road abrasion rates $[8,20,23,24]$. Indirect emissions from winter road maintenance activities such as the application of road sand (and to a lesser extent road salt) for traction control can be important $[8,25]$. While only $0.5 \%$ of road salt became suspended, salting was attributed to $1-10 \%$ of total $\mathrm{PM}_{10}$ emissions [21]. Through its control on both road dust generation and emissions, local meteorology can cause to up to a $60 \%$ variation in mean winter $\mathrm{PM}_{10}$ concentrations $[21,24]$. Surface wetness is an effective particle binder, contributing to the buildup of dust to be released episodically during dry periods $[24,26]$. To the authors' best knowledge, no study has systematically assessed the contribution of individual weather parameters on the fate of suspendable road dust.

Even if many cities have readily switched to newer, lower-polluting vehicles (e.g., Euro 5 and Euro 6) and made major investments in sustainable and shared mobility, their ambient air still often exceeds the European standard for $\mathrm{PM}_{10}$ [27]. Many of these cities have applied a host of short- and long-term mitigation measures to limit road dust emissions, such as speed reductions, studded tire bans, stronger bitumen asphalt, and the application of dust-binding and road cleaning chemical agents with some success [21,26]. As winter temperature, atmospheric humidity, and precipitation increase in many parts of the world due to climate warming, maritime winter conditions with frequent snow and frost cycles may become more prevalent in high-latitude regions [28]. The degree to which these wet, oscillating weather conditions affect the magnitude and fate of road dust is not fully understood.

Attaining joint environmental, economic, and societal benefits of a sustainable city requires a detailed knowledge of the interplay between the road surface, traffic, and meteorological conditions. The goal of this research was, therefore, to assess the anthropogenic levers of road dust generation and meteorological conditions governing the environmental fate of non-exhaust particles, as a foundation for mitigation policy-making. To compliment previous research undertaken in the northern parts of continental Europe and North America, this study focuses on the subpolar, oceanic climate of Reykjavík, the capital and largest city of Iceland. Reykjavik undergoes frequent freeze-thaw cycles and high amounts of winter precipitation. The study addresses the following questions: (1) Which meteorological driver most strongly governs the partitioning between atmospheric and 
water bound traffic related $\mathrm{PM}_{10}$ particles? (2) Which actions are required to achieve the goals of no exceedances to air quality standards of particulate matter? (3) Which air quality mitigation method(s) can achieve the broadest benefits of sustainable cities? To answer these questions, a numerical model was used to incorporate the complex interplay and feedback mechanisms amongst anthropogenic processes and the hydro- and atmospheres. Simulations were compared to other sites with different climatic conditions.

\section{Materials and Methods}

\subsection{Site}

The Icelandic Capital Region (ICR), which includes the City of Reykjavík and five surrounding municipalities, has a subpolar, oceanic climate characterized by frequent precipitation, freeze-thaw cycles, and a narrow annual temperature range [29]. Despite a relatively small population ( 220,000 inhabitants in 2020), particulate matter exceeds the 24-h European Health Safety Standards (EHSS) of $50 \mu \mathrm{g} / \mathrm{m}^{3}$ of $\mathrm{PM}_{10}$ from 7 to 30 times per year on average (Figure 2). Asphalt wear was attributed to approximately half of the measured $\mathrm{PM}_{10}$ in a series of source apportionment studies [30,31]. Tire wear, and to a much lesser extent road markings, was estimated to contribute to approximately $80 \%$ of microplastic generation in Iceland [32]. Given the range of episodic, but large, sources of $\mathrm{PM}_{10}$ causing exceedances of the EHSS, such as ash and dust storms, local resuspension, long-range transport, and fireworks [33-36], there is a dire need to reduce the exceedances associated with traffic.

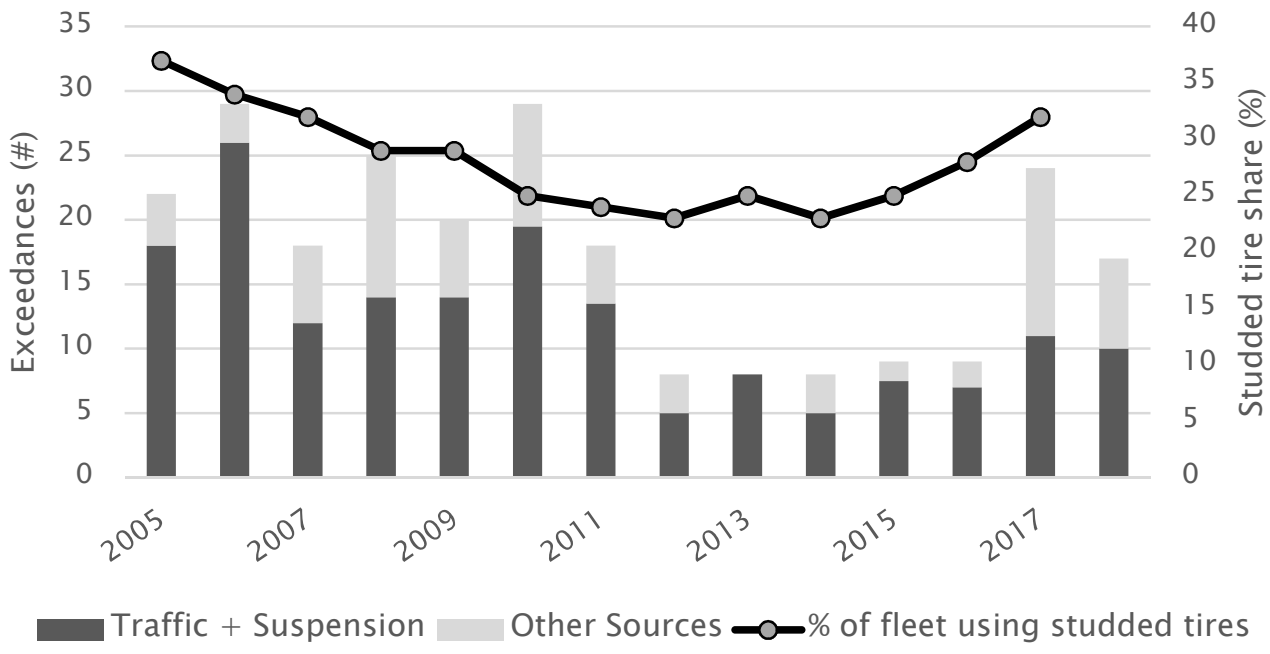

Figure 2. Annual exceedances of 24-h health safety limits and average share of Light Duty Vehicles on studded tires (data taken from in $[37,38]$ ).

\subsection{Approach}

The NORTRIP (Non-Exhaust Road Traffic Induced Particle) model is a comprehensive non-exhaust emissions model developed in collaboration between various Nordic governmental agencies and academics [39]. The model was selected because of its proven ability to (1) reproduce measured concentrations of particulate matter with satisfactory accuracy for sites in Fennoscandia [23,24,39,40], (2) assess the climatic and anthropogenic influences on the sources and sinks of non-exhaust particles, and (3) replicate the successes of mitigation strategies [21]. The model sensitivity to varying mitigation actions and different local meteorology, was tested. The results were interpreted in relation to previous studies.

\subsection{Data}

The Kauptún site is a four-lane urban traffic artery situated in an open lava field in the municipality of Garðabær (Figure 3a). The road experienced a steady increase in 
traffic volume in the aftermath of the 2007-2008 financial crisis (Figure 3b). The Kauptún site was equipped with traffic data counters and weight sensors to distinguish light(LDV) or heavy-duty (HDV) vehicles, as well as a meteorological station recording wind, air temperature, road surface temperature, and conductivity. Moreover, information about road and winter management was available from the Icelandic Road \& Coastal Administration [41]. Studded tire counts were conducted every five weeks based on a sample of 250 parked passenger vehicles in parking lots at two shopping centers, a university, and in the city center [38]. The chosen locations targeted vehicles owned by the local inhabitants. Rental vehicles, all of which were on studded tires in winter, may be underrepresented.

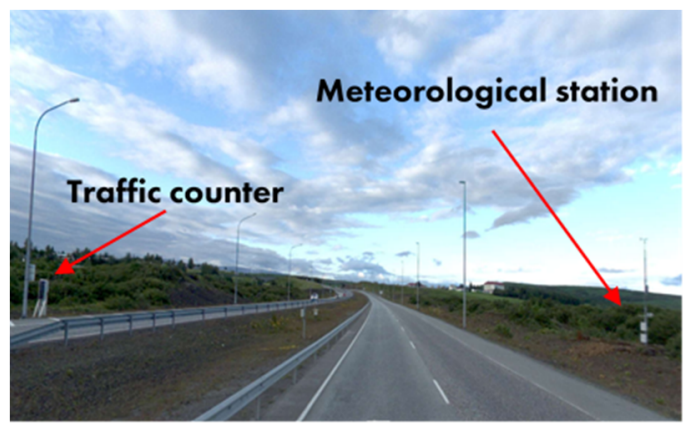

(a)

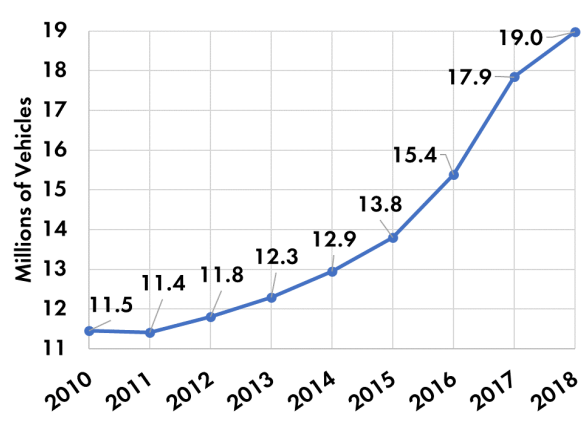

(b)

Figure 3. Kauptún study site. (a) Overview. (b) Traffic volume trends (data taken from in [41]).

Precipitation and net short-wave radiation data were obtained from the Icelandic Meteorological Office in Reykjavik [42]. The hourly precipitation was partitioned between rain (total $425 \mathrm{~mm}$; max $6.3 \mathrm{~mm} / \mathrm{hr}$ ) and snow (total $81 \mathrm{~mm}$; max $2.9 \mathrm{~mm} / \mathrm{hr}$ ), using a temperature threshold based on relative humidity $(\mathrm{RH})$,

$$
T R H=0.75+0.85(100 \%-R H)
$$

If the air temperature exceeded $T R H$, then precipitation was treated as rainfall; otherwise, it was treated as snowfall [43].

Air quality data from the fixed, urban traffic station at Grensás, Reykjavík, were used for comparison [37]. The data sites had similar topographical features. Grensás, however, had a higher traffic (38 million cars annually) than the study site Kauptún (19 million cars annually).

\subsection{Baseline Model Setup}

The simulation period was defined as 15 October 2017 to 1 May 2018 representing 15 days before and after the legal period for use of studded tires in Iceland. Comparing the key model inputs to previous NORTRIP model sites (Table 1), Kauptún tends to be more humid, windy, and wet, with lower solar radiation to warm up and dry the bitumen road surface, and more winter road management activities such as salting and snow ploughing. The atmospheric $\mathrm{PM}_{10}$ concentration was simulated using the Operational Street Pollution Model (OSPM). Although designed to calculate dispersion within street canyons [44], a characteristic that does not apply to the study site, it generated significantly more stable and realistic concentrations than the primary NORTRIP option of utilizing the closest available $\mathrm{NO}_{x}$ data to calculate concentrations. Most of the default NORTRIP settings were used in accordance with previous applications of the model. However, some parameters such as asphalt characteristics were altered to better represent the specific conditions of the investigated site. 
Table 1. Key model input and output parameters for baseline simulations in three Nordic cities.

\begin{tabular}{|c|c|c|c|c|}
\hline & & Hornsgatan $^{a}$ & $\mathrm{RV} 4^{\mathrm{a}}$ & Kauptún \\
\hline & & Stockholm & Oslo & Garðabær \\
\hline \multirow{2}{*}{ Simulation } & Latitude & $59.3^{\circ} \mathrm{N}$ & $59.9^{\circ} \mathrm{N}$ & $64.1^{\circ} \mathrm{N}$ \\
\hline & Period (winter; nr. of days) & $2006-2007 ; 243$ & $2004 ; 121$ & 2017-2018; 196 \\
\hline \multirow{5}{*}{$\begin{array}{l}\text { Traffic \& } \\
\text { Pavement }\end{array}$} & $\begin{array}{c}\text { Annual average daily traffic }\left(\times 10^{3}\right. \\
\text { vehicles })\end{array}$ & 29.1 & 42.6 & 51 \\
\hline & Heavy duty vehicles share (\%) & 3 & 4.9 & 9 \\
\hline & Mean/Max studded tires (\% LDV) & $47 / 75$ & $26 / 27$ & $23 / 46$ \\
\hline & Mean speed $(\mathrm{km} / \mathrm{hr})$ & 43 & 75 & 80 \\
\hline & Pavement type factor $\left(h_{\text {pave }}\right)$ & 0.83 & 1.6 & 1.62 \\
\hline \multirow{6}{*}{ Meteorology } & Mean short wave radiation $\left(\mathrm{W} / \mathrm{m}^{2}\right)$ & $66^{b}$ & $57^{b}$ & 37 \\
\hline & Mean air temperature $\left({ }^{\circ} \mathrm{C}\right)$ & 5.8 & 1.0 & 1.0 \\
\hline & Relative humidity (\%) & 75 & 76 & 82 \\
\hline & Total precipitation (mm) & 197 & 178 & 507 \\
\hline & Precipitation frequency (\%) & 5.8 & 13 & 17 \\
\hline & Mean wind speed at $10 \mathrm{~m}(\mathrm{~m} / \mathrm{s})$ & 4.0 & 2.5 & $6.0^{c}$ \\
\hline \multirow{3}{*}{$\begin{array}{c}\text { Winter } \\
\text { Management }\end{array}$} & Total salt (ton/km) & 6.3 & 39 & 14 \\
\hline & Salting events $(\mathrm{NaCl})$ & 45 & 113 & $526^{d}$ \\
\hline & Ploughing events & 2 & 9 & $115^{\mathrm{d}}$ \\
\hline \multirow{2}{*}{$\begin{array}{l}\text { Model } \\
\text { Outcomes }\end{array}$} & Wet roads frequency $(\%)$ & 43 & 48 & 53 \\
\hline & $\begin{array}{c}\text { Net mean/90th percentile } \mathrm{PM}_{10} \\
\qquad\left(\mu \mathrm{g} / \mathrm{m}^{3}\right)\end{array}$ & $39 / 90$ & $30 / 80$ & $20 / 49$ \\
\hline
\end{tabular}

Notes: ${ }^{\mathrm{a}}$ Norman et al. (2016); ${ }^{\mathrm{b}}$ Global radiance, $I$, converted to incoming short-wave radiation using mean cloud cover, $n$, as $\mathrm{SW}_{\text {in }}=I \times\left(1-0.75 \times n^{3.4}\right) ;{ }^{c}$ Wind speed at $2 \mathrm{~m}(4.0 \mathrm{~m} / \mathrm{s})$ upscaled to $10 \mathrm{~m}$ elevation using the logarithmic law for neutral conditions $(10 / 2)^{0.25} ; \mathrm{d}$ Multiple salting and ploughing events per day. Abbreviation: LDV = Light-Duty Vehicle.

Baseline simulations assumed a typical Icelandic asphalt, with local aggregate hardness as 7.9 Nordic ball mill (NBM). The maximum stone size (MS) was $16 \mathrm{~mm}$, and the percentage of stone size greater than $4 \mathrm{~mm}$ was $65 \%$. The pavement type factor $\left(h_{\text {pave }}\right)$ was characterized using the Swedish Road Wear Model [45] as

$$
h_{\text {pave }}=2.49+0.144 \cdot N B M-0.069 \cdot M S-0.017 \cdot S_{>4 \mathrm{~mm}} .
$$

The resulting value was $1.62 \mathrm{~g} / \mathrm{km} / \mathrm{veh}$ corresponds to a higher wear rate than the reference in NORTRIP (4.68 vs. $2.88 \mathrm{~g} / \mathrm{km} / \mathrm{veh}$, respectively). A more thorough description of the inputs and model setup is presented in the master's thesis by Brian C. Barr [46].

\subsection{Sensitivity Analysis}

A sensitivity analysis was conducted to understand which lever, either anthropogenic or meteorological, was most significant for PM generation and release of PM, to the atmosphere and waterways. Traffic-related parameters, such as studded tire share, traffic volume and speed, and the fraction of HDVs, were increased or decreased on percentage bases.

Incremental changes in meteorological conditions were simulated without changing road management practices. This approach gives an indication of lever strength but is not meant for forecasting purposes. Temperatures and relative humidity were raised or lowered by a uniform amount, and the amount of rain and snow values adjusted according to Equation (1). Precipitation frequency was reduced by eliminating the mildest precipitation $(0.1-0.4 \mathrm{~mm} / \mathrm{hr})$ and increased by adding the minimum threshold precipitation $(0.1 \mathrm{~mm} / \mathrm{hr})$ during dry periods with relative humidity exceeding different thresholds $(>97,98$, and $99 \%)$. Precipitation intensity was investigated by proportionally increasing or reducing the amount of precipitation that occurred for each hourly data point. The interdependence of different meteorological variables, e.g., climate warming and relative humidity [29], and to which degree such parameters reinforce or balance each other was not a focus of this study. 
Three non-realistic ("extreme") precipitation scenarios were applied to better understand the control of road wetness and precipitation phase. Furthermore, simulations were conducted with proportionally changing the amount of road salt applied and incorporating cleaning and wetting. No simulations were performed using sanding, because sanding is not applied at this site, and sanding is not yet fully developed in the NORTRIP model $[24,40]$. Last, the sensitivity of the model was tested by increasing the hardness of the aggregate (NBM).

\subsection{Model Outputs}

Air quality was primarily assessed based on three metrics: the average $\mathrm{PM}_{10}$ concentrations during simulation period as related to annual guidelines (40 and $20 \mu \mathrm{g} / \mathrm{m}^{3}$ according to European Air Quality Directive and WHO guidelines, respectively $[47,48])$, the number of exceedances to the European Standard of $24 \mathrm{~h} \mathrm{PM} 10$ of $50 \mu \mathrm{g} / \mathrm{m}^{3}$, and the maximum daily $\mathrm{PM}_{10}$ concentrations.

Road surface conditions were primarily assessed by surface wetness, as the percentage of total time that roads were wet. The key metric used to gauge the need for winter management was the number of days when road ice was above the $0.1 \mathrm{~mm}$ threshold.

Road wear is mainly represented as a function of traffic (i.e., vehicle count, $L D V$ vs. $H D V$, and speed), and road surface strength in the NORTRIP model [39]. Sand sources (road abrasion and crushing) were not relevant in this study. The generated road dust is either directly emitted to the atmosphere or retained on the road surface (wear retention), which is subsequently removed from the road surface via four sink mechanisms: (1) Atmospheric suspension due to the contact of tires with a dry road surface; (2) spray, because of tire contact with a wet road; (3) drainage into the stormwater collection system via street inlets; and (4) windblown material, negligible in all simulations and not discussed further. The sink terms are either presented as rates $\left(\mathrm{g} / \mathrm{m}^{2} / \mathrm{hr}\right)$ or as cumulative mass over the simulation period.

Cumulative dust generation, including both the instantaneous losses to atmosphere and wear retention, was estimated by summing up all sink terms during a simulation with continuous mild $(0.1 \mathrm{~mm} / \mathrm{hr})$ rainfall as $2219 \mathrm{~g} / \mathrm{m}^{2}$.

Mass loading $\left(\mathrm{g} / \mathrm{m}^{2}\right)$ represents the mass of road dust and sand that accumulates on the road surface.

\section{Results}

\subsection{Baseline Simulation}

The model was effective at representing the timing of observed $\mathrm{PM}_{10}$ episodes at the urban traffic air quality station in Reykjavík (Figure 4a), but tended to overpredict concentrations, particularly during the nearly sunless months of December and January. Concentrations of $\mathrm{PM}_{10}$ were overestimated by $22 \%$ on average during the simulation period, resulting in 20 modeled Health Safety Limit (HSL) exceedances, as opposed to 13 observed ones. The New Year's Eve exceedance was due to fireworks and as such, not represented in the model. Overall, the 0.57 correlation coefficient between modeled and observed particulate matter concentrations was comparable to other Scandinavian studies, and as such, is considered a satisfactory performance. 


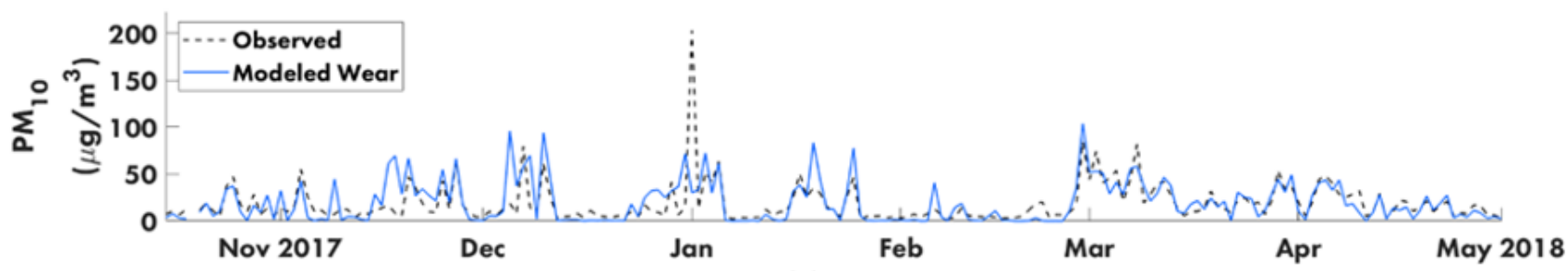

(a)

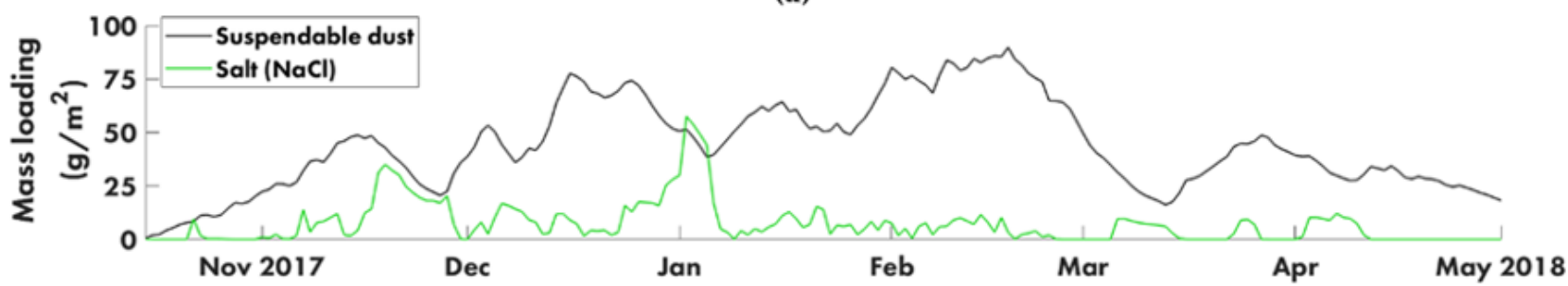

(b)

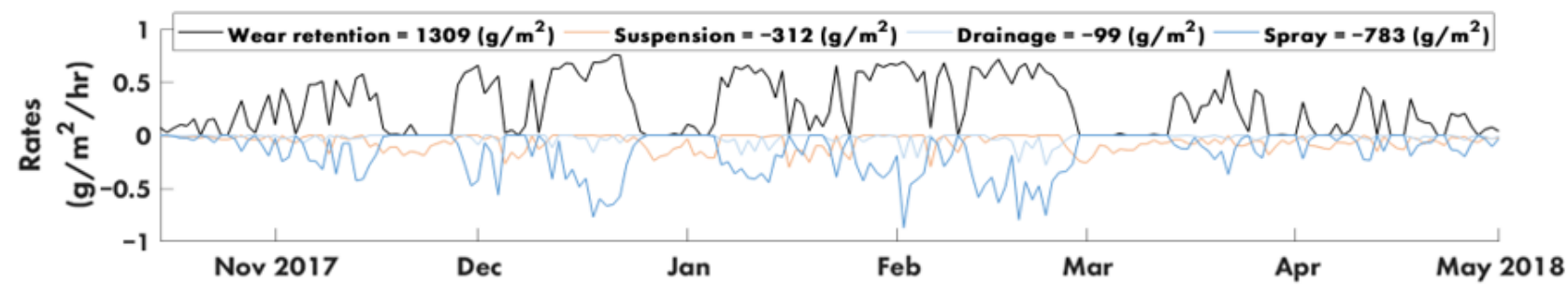

(c)

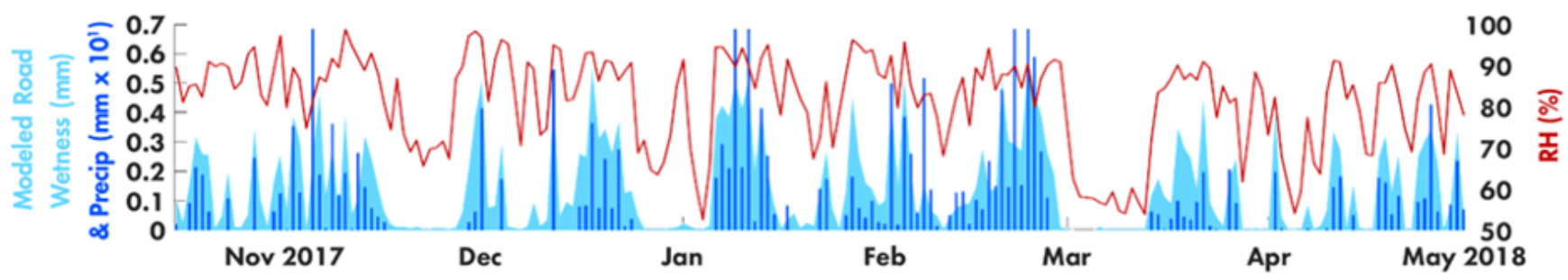

(d)

Figure 4. Daily baseline simulation outputs at Kauptún during winter 2017/2018. (a) Modeled and observed PM 10 concentrations. (b) Amount of dust accumulated on the surface of the road that is available for resuspension. (c) Source and sink rates for accumulation of dust on the road surface. (d) Daily modeled road wetness (shade), precipitation (bars), and relative humidity (line).

A progressive accumulation of road dust was predicted as increasing number of vehicles using studded tires were included in the model (Figure $4 \mathrm{~b}$ ). More dust was retained on the roads during wet periods (Figure 4c), but at the same time, the removal mechanisms of spray and drainage became more effective, reducing the amount of dust available to be suspended in air. Once the road dried (reducing road wetness, Figure $4 \mathrm{~d}$ ), the source and water-related sink terms became negligible while suspension, due to tire contact with the road, begins, elevating the particulate matter concentrations in the air (Figure $4 \mathrm{a}$ ) and reducing the mass loading on the road (Figure $4 \mathrm{~b}$ ). Of particular note are the few dry periods promoting atmospheric releases in the months of November through February. As a result, considerable amounts of dust accumulated on the road to be released during a series of closely spaced spring dust episodes.

Predicted road wetness correlated well with measured precipitation and relatively humidity (Figure 4d). Specifically, the road dried quickly after precipitation ended, usually within a few hours. Additionally, dry roads corresponded well with times when relative humidity dropped below $70 \%$. Albeit infrequent, wet roads were predicted on days with no precipitation, but elevated relative humidity. This suggests that precipitation and relative 
humidity can be used as indicators of road wetness, and by extension, can be used to anticipate periods of elevated dust suspension.

\subsection{Sensitivity to Traffic and Pavement Parameters}

The model predicts a near linear deterioration in air quality in response to increasing traffic-related parameters (Table 2). The fraction of light-duty vehicles on studded tires is identified as the single most influential traffic-related parameter to air quality: A 10\% reduction in the usage of studded tires resulted in an $\sim 25 \%$ decrease in average $\mathrm{PM}_{10}$ concentrations, and a $10 \mu \mathrm{g} / \mathrm{m}^{3}$ drop in maximum daily $\mathrm{PM}_{10}$ concentration. According to the model, the studded tire usage of the light-duty vehicle fleet needs to go down to $15 \%$ in order to achieve zero exceedances of the health safety limit.

Table 2. Model sensitivity to traffic and pavement.

\begin{tabular}{|c|c|c|c|c|}
\hline Category & $\begin{array}{l}\text { Alteration from } \\
\text { Baseline }\end{array}$ & $\begin{array}{c}\Delta \underset{\left(\mu \mathrm{g} / \mathrm{m}^{3}\right)}{\operatorname{Max} \mathrm{PM}_{10}} \\
\end{array}$ & $\begin{array}{c}\Delta \text { Avg. } P_{10} \\
\left(\mu \mathrm{g} / \mathrm{m}^{3}\right)\end{array}$ & $\begin{array}{c}\Delta \text { HSL } \\
\text { Exceedances } \\
\text { (Days) }\end{array}$ \\
\hline Baseline & $46 \%$ Max ST & 104 & 21 & 20 \\
\hline Studded Tires & $\begin{array}{c}\text { 35\% Max } \\
25 \% \text { Max } \\
15 \% \text { Max } \\
0 \% \text { (full ST ban) }\end{array}$ & $\begin{array}{l}-21 \\
-39 \\
-58 \\
-80\end{array}$ & $\begin{array}{l}-4 \\
-7 \\
-10 \\
-16\end{array}$ & $\begin{array}{l}-7 \\
-16 \\
-20 \\
-20\end{array}$ \\
\hline Traffic Volume & $\begin{array}{l}-10 \% \\
-20 \%\end{array}$ & $\begin{array}{c}-7 \\
-15\end{array}$ & $\begin{array}{l}-2 \\
-4\end{array}$ & $\begin{array}{l}-3 \\
-6\end{array}$ \\
\hline Traffic Speed & $\begin{array}{l}-10 \% \\
-20 \%\end{array}$ & $\begin{array}{l}-4 \\
-9\end{array}$ & $\begin{array}{l}-2 \\
-4\end{array}$ & $\begin{array}{l}-2 \\
-6\end{array}$ \\
\hline Composition & HDVs Excluded & 0 & -2 & -2 \\
\hline $\begin{array}{c}\text { Wear resistant } \\
\text { DGP }\end{array}$ & $\begin{array}{c}h_{\text {pave }}=0.93 \\
h_{\text {pave }}=1.3 \\
h_{\text {pave }}=1.5\end{array}$ & $\begin{array}{l}-40 \\
-19 \\
-9\end{array}$ & $\begin{array}{l}-8 \\
-4 \\
-2\end{array}$ & $\begin{array}{l}-16 \\
-7 \\
-3\end{array}$ \\
\hline
\end{tabular}

Abbreviations: HSL = Health Safety Limit; ST = Studded tires; HDV = Heavy-Duty Vehicle; DGP = Dense Grade Pavement.

The model suggests that shortening the legal time to use studded tires does not reduce the number of exceedances to HSL (not shown), albeit it can moderate the concentrations early in the season. Average and maximum particulate matter concentrations dropped 2 and $7 \mu \mathrm{g} / \mathrm{m}^{3}$, respectively, for every $10 \%$ reduction in traffic volume, which can be traced back to the reduction in studded tires vehicles; a $10 \%$ reduction in traffic volume is tantamount to an approximately $4.6 \%$ reduction in studded tires. A $10 \%$ decrease in traffic speed had a similar effect as $10 \%$ reduction in traffic volume, except that daily maximum $\mathrm{PM}_{10}$ was not reduced as much (Table 2). Removing heavy-duty vehicles (HDVs) from this particular road segment, which represented $9 \%$ of the total traffic count, was predicted to slightly reduce the average $\mathrm{PM}_{10}$ concentrations and cause two fewer HSL exceedances. Last, resurfacing the road with a more wear-resistant dense graded pavement (DGP), similar to that at Hornsgatan in Stockholm (Table 1), would strongly reduce road dust generation and exceedances, more so than reducing traffic volume by $20 \%$.

\subsection{Sensitivity to Meteorology and Winter Management}

The model sensitivity to local meteorology was first tested by changing each parameter while maintaining others fixed (Table 3). The range tested was chosen to represent conditions at the two reference sites (Table 1). The results highlight that rainfall frequency, more so than rainfall intensity, controls the air quality (mean concentrations and exceedances) via the frequency of wet or icy roads. Relative humidity (RH) exerts a secondary control on road wetness, which translates to increasing atmospheric particulate matter mean concentrations and exceedances as RH is lower, but has limited effect on road ice and 
hence the need for road salting. Air temperature, however, highly influences road ice formation, and by extension, winter management practices, and it should be noted that the response was nonlinear. Lowering mean air temperature to or below freezing point affected average $\mathrm{PM}_{10}$ concentrations (and exceedances to ambient air quality standards) more than warming from the freezing point.

Table 3. Model sensitivity to meteorological parameters and road management practices.

\begin{tabular}{|c|c|c|c|c|c|}
\hline Category & Alteration from Baseline ${ }^{1}$ & $\begin{array}{c}\Delta \text { Avg. } P_{\left(\mu M_{10}\right.} \\
\left(\mu g / m^{3}\right)\end{array}$ & $\begin{array}{c}\Delta \text { HSL } \\
\text { Exceedances } \\
\text { (Days) }\end{array}$ & $\begin{array}{l}\Delta \% \text { Wet } \\
\text { Roads }\end{array}$ & $\begin{array}{c}\Delta \text { Road Ice > } \\
0.1 \mathrm{~mm} \text { (Days) }\end{array}$ \\
\hline Baseline & $507 \mathrm{~mm}$; frequency $17.1 \%$ & 20.5 & 20 & $53.3 \%$ & 38 \\
\hline $\begin{array}{l}\text { Precipitation } \\
\text { Frequency }\end{array}$ & $\begin{array}{l}+7.7 \% ; 544 \mathrm{~mm} \text { total } \\
\quad+5.6 \% ; 534 \mathrm{~mm} \\
\quad+3.9 \% ; 526 \mathrm{~mm} \\
-3.2 \% ; 492 \mathrm{~mm} \\
-6.3 \% ; 463 \mathrm{~mm} \\
-8.2 \% ; 436 \mathrm{~mm} \\
-9.8 \% ; 406 \mathrm{~mm}\end{array}$ & $\begin{array}{c}-2.8 \\
-2.2 \\
-1.8 \\
0.5 \\
1.3 \\
1.6 \\
2.1\end{array}$ & $\begin{array}{c}-4 \\
-3 \\
-3 \\
0 \\
0 \\
0 \\
0\end{array}$ & $\begin{array}{c}5.7 \% \\
4.2 \% \\
3.9 \% \\
-1.6 \% \\
-3.8 \% \\
-4.5 \% \\
-6.5 \%\end{array}$ & $\begin{array}{c}15 \\
13 \\
10 \\
0 \\
-2 \\
-4 \\
-11\end{array}$ \\
\hline $\begin{array}{l}\text { Relative } \\
\text { Humidity }\end{array}$ & $\begin{array}{c}-6 \% \text {; mean: } 77 \% \\
-4 \% \text {; mean: } 79 \% \\
-2 \% \text {; mean: } 81 \% \\
+2 \% \text {; mean: } 84 \% \text {; max: } 100 \%\end{array}$ & $\begin{array}{c}1.8 \\
1.2 \\
0.6 \\
-1.0\end{array}$ & $\begin{array}{c}2 \\
2 \\
0 \\
-1\end{array}$ & $\begin{array}{l}-4.8 \% \\
-3.2 \% \\
-1.6 \% \\
2.3 \%\end{array}$ & $\begin{array}{c}-1 \\
-1 \\
0 \\
0\end{array}$ \\
\hline $\begin{array}{c}\text { Air } \\
\text { Temperature }\end{array}$ & $\begin{array}{l}+5^{\circ} \mathrm{C} \text {; mean: } 6{ }^{\circ} \mathrm{C} \\
+2^{\circ} \mathrm{C} \text {; mean: } 3{ }^{\circ} \mathrm{C} \\
+1^{\circ} \mathrm{C} \text {; mean: } 2{ }^{\circ} \mathrm{C} \\
-1{ }^{\circ} \mathrm{C} \text {; mean: } 0{ }^{\circ} \mathrm{C} \\
-2{ }^{\circ} \mathrm{C} \text {; mean: }-1{ }^{\circ} \mathrm{C}\end{array}$ & $\begin{array}{c}0.5 \\
0.3 \\
0.4 \\
-0.9 \\
-1.6\end{array}$ & $\begin{array}{c}0 \\
1 \\
0 \\
-1 \\
-2\end{array}$ & $\begin{array}{c}-1.0 \% \\
0.0 \% \\
-1.0 \% \\
2.0 \% \\
4.0 \%\end{array}$ & $\begin{array}{c}-37 \\
-26 \\
-13 \\
23 \\
40\end{array}$ \\
\hline $\begin{array}{l}\text { Precipitation } \\
\text { Intensity }\end{array}$ & $\begin{array}{l}\times 1.20 ; 608 \mathrm{~mm} \text { total } \\
\times 0.80 ; 406 \mathrm{~mm} \text { total }\end{array}$ & $\begin{array}{c}-0.2 \\
0.4 \\
\end{array}$ & $\begin{array}{l}0 \\
0\end{array}$ & $\begin{array}{c}1.0 \% \\
-1.0 \% \\
\end{array}$ & $\begin{array}{c}2 \\
-1 \\
\end{array}$ \\
\hline $\begin{array}{l}\text { "Extreme" } \\
\text { Scenarios }\end{array}$ & $\begin{array}{c}\text { No precip } \\
\text { No precip; No WM } \\
\text { Rain only }\left(\mathrm{T}_{\text {air }} \geq 4{ }^{\circ} \mathrm{C}\right) ; \text { No WM } \\
\text { Constant rain }(0.1 \mathrm{~mm} / \mathrm{hr}) \\
475 \mathrm{~mm}\end{array}$ & $\begin{array}{c}6.1 \\
7.1 \\
-2.3 \\
-19.8\end{array}$ & $\begin{array}{c}7 \\
3 \\
-7 \\
-20\end{array}$ & $\begin{array}{l}-15 \% \\
-26 \% \\
3.0 \% \\
47 \%\end{array}$ & $\begin{array}{l}-36 \\
-36 \\
-38 \\
80\end{array}$ \\
\hline Salting & $\begin{array}{c}-50 \% \\
50 \%\end{array}$ & $\begin{array}{c}-0.8 \\
1.2\end{array}$ & $\begin{array}{l}1 \\
2\end{array}$ & $\begin{array}{c}1.0 \% \\
-1.0 \%\end{array}$ & $\begin{array}{c}3 \\
-3\end{array}$ \\
\hline Wetting & $\begin{array}{l}0.2 \mathrm{~mm} \text { every four hours during } \\
\text { long, dry periods }\end{array}$ & -4.2 & -9 & $11 \%$ & 16 \\
\hline
\end{tabular}

Note: ${ }^{1}$ Winter management (WM) practices same as in base line simulation, unless otherwise noted.

The "extreme" scenarios provide additional insights to the control of precipitation and road management on particulate matter pollution. In the absence of precipitation, the mean $\mathrm{PM}_{10}$ concentrations would be higher, and more exceedances of the air quality standards would occur, in accordance with wet removal processes being eliminated. Discontinuing winter salting and plowing results in fewer exceedances to air quality standards. If all the precipitation would fall as rainfall, so no winter management would be needed, the average $\mathrm{PM}_{10}$ concentration is lowered by $10 \mu \mathrm{g} / \mathrm{m}^{3}$, and the number of exceedances reduced by one-third. Therefore, winter management is a secondary, yet significant, contributor to particulate matter pollution.

A more aggressive salting scenario increased road dust on the same order of magnitude as a moderate change in meteorological conditions $\left(1 \mu \mathrm{g} / \mathrm{m}^{3}\right.$ mean $\left.\mathrm{PM}_{10}\right)$. Salt has the potential to increase moisture, which itself has a mitigating effect on suspension (Denby et al., 2012). Road wetting on an as-needed basis (Table 3) almost reduces the exceedances to national health safety limits by half, in accordance with the strong dependence on precipitation frequency. 


\subsection{Fate of Road Dust}

Of the $2219 \mathrm{~g} / \mathrm{m}^{2}$ of road dust generated over the 6.5-month simulation period, $41 \%$ was directly emitted to the atmosphere and $14 \%$ suspended during dry periods with traffic. The major wet removal process was spray, predicted to remove $35 \%$ of the generated dust off the road to the roadside curb. Direct drainage to waterways via the stormwater collection system constituted only $4.5 \%$. Of the meteorological factors tested, rainfall frequency controlled most whether road dust was emitted to the atmosphere or became water bound (Figure 5). Most notably, more frequent rainfall, and to a lesser extent higher atmospheric humidity, shifted direct emissions to wet removal via spray (Figure 5a,b). In the unrealistic extreme condition of constant, mild rainfall, $89 \%$ of the generated dust would leave the road surface via spray. The response to air temperature was much less pronounced and nonlinear around freezing point, where atmospheric emissions were predicted to be at minimum (Figure 5c). Increasing rainfall intensity shifted only slightly the removal from the atmosphere to wet removal (Figure $5 \mathrm{~d}$ ). Of all the meteorological parameters tested though, rainfall intensity exerted one of the strongest controls on drainage to waterways. For example, a $10 \%$ increase in rainfall intensity resulted in a $6 \mathrm{~g} / \mathrm{m}^{2}$ increase equally to spray and drainage. At the end of the simulation period, all scenarios tested suggested that around $110 \mathrm{~g} / \mathrm{m}^{2}$ of the generated road dust was still present on the road to be removed at a later time (noted as mass loading; Figure 5).

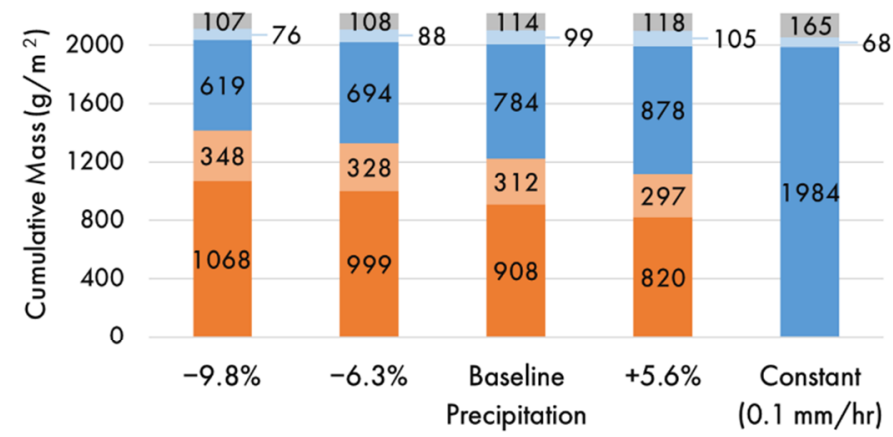

(a)

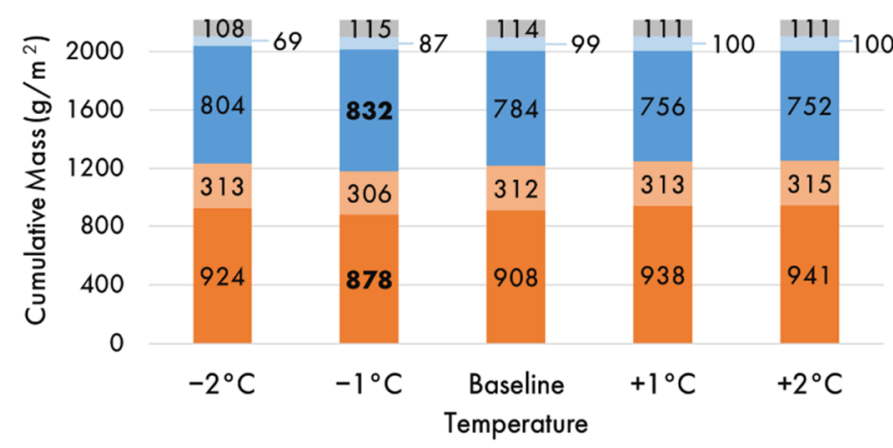

(c)

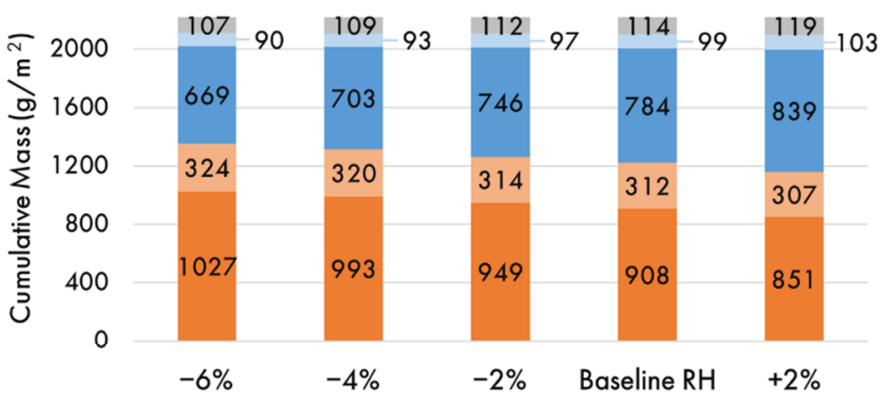

(b)

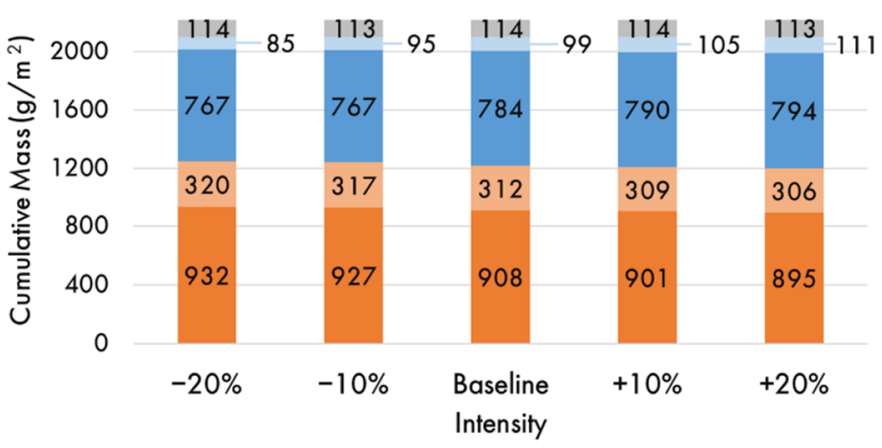

(d)

Direct Emissions $\square$ Suspension $\square$ Spray $\square$ Drainage $\square$ Mass Loading

Figure 5. Sensitivity of wet (blue) and dry (orange) removal processes to individual meteorological parameters: (a) Precipitation frequency; (b) Relative humidity; (c) Air temperature and precipitation phase; (d) Precipitation intensity.

\section{Discussion}

\subsection{Wet Maritime Climate}

This study expands the current knowledge of non-exhaust particulate pollution by considering the wet, humid, windy, and sunless maritime climate in the Icelandic Capital Region compared to other studied capitals in Northern Europe (Table 1). NORTRIP model sensitivity analyses highlight these climatic attributes (frequent rain, high humidity) as 
efficient dust retention and wet removal processes, which are primarily spray and secondarily drainage (Table 3, Figure 5). Therefore, maritime, wet, and cold conditions promote microplastics loading to aquatic and terrestrial environments, estimated as representing $45 \%$ of the total mass of $\mathrm{PM}_{10}$ particles generated. The positive effect of this efficient wet removal of dust is the moderate average winter $\mathrm{PM}_{10}$ concentration that almost adheres to the WHO guidelines of $20 \mu \mathrm{g} / \mathrm{m}^{3}$, and $50 \%$ to $100 \%$ lower when compared to Oslo and Stockholm (Table 1), despite the greater traffic volume. Unfortunate artifacts of prolonged wet roads ( $53 \%$ of time) are closely spaced, intense particulate matter episodes, both midwinter and in springtime (Figure 4a). The potential effect of frequent freeze thaw cycles on road dust generation was not resolved in this study, as it was beyond the capability of the NORTRIP model. Previous research suggests a faster pavement deterioration in wet areas with frequent freeze-thaw cycles $[16,49]$.

\subsection{Mitigation Strategies for Atmospheric $P M_{10}$}

The model identified the primary lever for road dust generation and abatement as reducing the number of light-duty vehicles on studded tires (Table 2). Traffic volume and asphalt type were secondary levers, followed by vehicle speed. Only a drastic reduction of studded tires usage in winter achieved the goals of adhering to ambient air quality standards. Yet, the share of light duty vehicles on studded tires has steadily increased since 2014 (Figure 2), partially as the public campaign "Off with the studded tires" (Icelandic: "Burt með nagladekkin") was relaxed. In addition, episodic road ice conditions forming in October just before the studded tires legal interval (Nov. 15) prompt car owners to choose studded tires, despite that Reykjavík Municipality winter management services are frequent enough that studded tires are not needed within the city perimeter. Moreover, traffic volume has been drastically increasing over the past years (Figure 3b), both because of personal car ownership and tourism. Considering these historical trends in studded tire use and traffic volume, it is unlikely that focusing solely on the optimal levers will result in a timely improvement in air quality. Therefore, it is important to evaluate combined mitigation strategies; both short-term when episodes are expected, and long-term.

Short-term response to foreseeable PM episodes: The strong correlation between modeled road wetness, precipitation, and relative humidity (Figure $4 \mathrm{~d}$ ) suggests that the risk of $\mathrm{PM}_{10}$ episodes can be predicted based on periods of prolonged road dryness and high dust load. This allows authorities to implement preemptive, short-term mitigating actions to stifle the suspension of dust. One mitigation action that has been employed in cities facing severe pollution episodes, locally called "gray days", is to ban cars with an even or odd license plate from driving in the city. This aggressive, active, short-term measure alone, however, would not alleviate the problem with exceedances. However, coupling $50 \%$ reduction in traffic volume with a $10 \mathrm{~km} / \mathrm{h}$ speed limit reduction brings the number of traffic related HSL exceedances to two (Table 4). An alternative, less intrusive approach is to wet the road system on gray days as a dust binding measure. This, combined with slight traffic and speed reductions, is predicted to lower the $\mathrm{PM}_{10}$ concentrations during episodes to one-third. While a significant reduction, it still does not achieve the Icelandic government's goal of zero traffic-related $\mathrm{PM}_{10}$ exceedances by 2029. It is important to keep in mind that short-term mitigation strategies are focused on reducing the suspension of $\mathrm{PM}_{10}$, not the generation. The short timeframe of these measure does not influence the long-term dust generation, and as such, the loading of road dust to terrestrial and aquatic environments. 
Table 4. Selected combined short and long-term mitigation strategies.

\begin{tabular}{|c|c|c|c|c|c|c|}
\hline \multirow[b]{2}{*}{ Mitigation Scenario } & \multicolumn{4}{|c|}{ Targets } & \multicolumn{2}{|c|}{ Air Quality Outcomes } \\
\hline & $\begin{array}{c}\text { Traffic Volume } \\
\text { Reduction }\end{array}$ & $\begin{array}{c}\text { Speed } \\
\text { Reduction }\end{array}$ & $\begin{array}{l}\text { Max. Studded } \\
\text { Tire Usage }\end{array}$ & $\begin{array}{c}\text { Road } \\
\text { Re-Surfacing }\end{array}$ & $\begin{array}{l}\text { Avg } \mathrm{PM}_{10} \\
\text { Reduction }\end{array}$ & $\begin{array}{c}\text { Total HSL } \\
\text { Exceedances }\end{array}$ \\
\hline Short-Term-Aggressive & $50 \%$ & $15 \mathrm{~km} / \mathrm{h}$ & Unchanged & No & $44 \%$ & 2 \\
\hline Short-Term-Moderate & $10 \%$ & $10 \mathrm{~km} / \mathrm{h}$ & Unchanged & No & $33 \%$ & 5 \\
\hline Long-Term-Aggressive & $15 \%$ & None & $20 \%$ & No & $50 \%$ & 0 \\
\hline Long-Term-Moderate I & $10 \%$ & $10 \mathrm{~km} / \mathrm{h}$ & $25 \%$ & No & $41 \%$ & 2 \\
\hline Long-Term-Moderate II & $10 \%$ & None & $25 \%$ & Yes & $63 \%$ & 0 \\
\hline
\end{tabular}

Long-term mitigation actions: The sensitivity analysis suggests that the long-term strategy needs to be focused on reducing the use of studded tires as much as possible; coupling this with a decrease in traffic volume would further decrease the overall number of studded tires. Historically, the lowest seasonal average percentage of studded tires was 23\% in both 2012 and 2014 (Figure 2). From this perspective, an aggressive scenario is to half the number of studded tires ( $20 \%$ maximum) in 9 years. Yet, this provision does not suffice to achieve the goal of zero $\mathrm{PM}_{10}$ exceedances, so a $15 \%$ reduction in traffic volume must be implemented as well (Table 4). A less aggressive approach would be to reduce studded tire use to $25 \%$, and traffic speed permanently by $10 \mathrm{~km} / \mathrm{h}$; this would lower the average $\mathrm{PM}_{10}$ concentrations by $41 \%$. Finally, road resurfacing would offer significant long-term dust reduction, but its effectiveness increases substantially when coupled with reductions in studded tire usage. Road resurfacing with a similar asphalt strength as used at Hornsgatan resulted in a $40 \%$ reduction in emissions in the model; this reduction increases to $63 \%$ when coupled with aggressive studded tire reduction.

\subsection{Mitigation Strategies for Sustainable Cities}

As discussed in the previous section, a combination of different mitigation actions can help achieve the overall goal of zero road dust related particulate matter exceedances. However, in a broader context, it is important to recognize that some actions may provide auxiliary environmental benefits, such as greenhouse gas and noise abatement, while other may be more costly and take a long time to implement. Therefore, it is valuable to extend the criteria of beneficial outcomes to incorporate more multifaceted goals of a sustainable city. We will consider the anthropogenic levers tested in the NORTRIP model together with two new levers for comparison, the electrification of the car fleet and dust binding with agents such calcium magnesium acetate (CMA), which has effectively reduced peaks in $\mathrm{PM}_{10}$ concentrations [5]. Each lever was given a score based on its positive or negative contribution to goals of sustainability as stated in literature.

By considering more amenities than road dust generation, traffic reduction provided the most intense and diverse environmental benefits (Table 5). Moreover, fewer cars on the street drastically reduces collision rates and as such, this lever is ranked highest on safety. However, reducing personal cars requires a public transport alternative which may require substantial investment and may take a long time to implement [27]. Reducing studded tires is an effective noise and road dust abatement technique in cold climates. This measure, however, lacks climate resilience because of exhaust gas emissions and may raise winter safety concerns. Lowering speed limits contributes positively, albeit moderately, on all the diverse aspects of a sustainable city. Lower vehicle velocity generates less exhaust gases and noise [50] as well as road dust, but it should be kept in mind that more road dust is removed as drainage to local waterways due to lower suspension between tire and road surface. Its competitive advantage over the other traffic levers is, arguably, its ease and speed of implementation. Vehicle electrification provides only a reduction of harmful exhaust pollutants such as greenhouse gases [51], black carbon, and nitrogen oxides. While highly important, it cannot be the backbone of a strategy for sustainable cities because of concerns that electrical vehicles emit more road dust because of their greater weight 
compared to internal combustion vehicles [52], and of the natural resources depleted in converting the car fleet and time of implementation [53].

Table 5. Evaluation of multifaceted benefits of anthropogenic levers in a subpolar, oceanic climate.

\begin{tabular}{|c|c|c|c|c|c|c|c|c|}
\hline \multirow[b]{2}{*}{ Domain } & \multirow[b]{2}{*}{ Anthropogenic Lever } & \multicolumn{4}{|c|}{ Environmental Benefits } & \multirow{2}{*}{$\begin{array}{c}\begin{array}{c}\text { Social } \\
\text { Benefits }\end{array} \\
\text { Safety }\end{array}$} & \multicolumn{2}{|c|}{$\begin{array}{c}\text { Logistics of } \\
\text { Implementation }\end{array}$} \\
\hline & & $\begin{array}{l}\text { Non- } \\
\text { Exhaust }\end{array}$ & $\begin{array}{c}\text { Exhaust } \\
\text { (e.g., } \\
\text { GHG) }\end{array}$ & Noise & $\begin{array}{c}\text { Resource } \\
\text { Efficiency }\end{array}$ & & Cost & Time \\
\hline \multirow{4}{*}{ Traffic } & Reduce traffic volume & + & + & + & ++ & ++ & -- & 12 years ${ }^{2}$ \\
\hline & Reduce studded tires & ++ & / & ++ & + & - & + & $2+$ years $^{2}$ \\
\hline & Reduce speed & + & + & + & + & + & ++ & Days \\
\hline & Increase electrical cars & - & ++ & / & - & / & / & 12 years $^{2}$ \\
\hline \multirow{2}{*}{ Pavement } & Wear-resistant DGP & + & / & / & + & / & -- & $6+$ year $^{2}$ \\
\hline & Open-graded OGP & - & / & + & - & +1 & - & 2 years $^{2}$ \\
\hline Road & Dust binding & $(+)$ & / & / & - & / & - & Hours \\
\hline Management & Road wetting & $(+)$ & / & / & - & - & - & Hours \\
\hline
\end{tabular}

Notes: Scale: ++ = Highly positive effect; + = Positive effect; / = Neutral/Unknown/Varies; $-=$ Negative effect; $--=$ Highly negative effect; ${ }^{1}$ Construction and rehabilitation needs for road infrastructure (pavements, bridges, parking lots). ${ }^{2}$ Based on longevity of studded tires; personal vehicles; pavement. Abbreviations: GHG = Green House Gases; DGP/OGP = Dense/Open Graded Pavement.

The last four levers pertain to changing the properties of the road surface. The first lever is to increase the aggregate hardness (lower NBM) or the percentage of stones > $4 \mathrm{~mm}$ (Equation (2)) in dense pavement asphalt (DGP), as tested in the sensitivity analysis (Table 2). While this reduces road dust generation, and improves resource efficiency through less pavement wear, it is not expected to create additional benefits such as improved safety or reduced noise levels. Moreover, road resurfacing is only done at $6+$ year intervals, and a stronger aggregate may not be found locally, as is the case in Iceland. An importation of stronger aggregates would thus increase greenhouse gas emissions from shipping. For comparison purposes, open-graded (OGP), permeable friction course pavements offer a host of safety and environmental benefits, including improved wet weather skid resistance, reduced splash and spray, reduced light reflection, reduced tire and pavement noise, improved pavement smoothness, reduced contribution to urban heat island effect, and reduced pollutant loadings in stormwater runoff [19]. However, they perform worse than DGP in winter, as they freeze faster and longer, need more deicing agents, their pores can store and retain snow and dust, and their aggregate structure makes them particularly susceptible to degradation, especially by studded tires $[19,26,54]$. Last, the short-term road management actions of dust binding provide no auxiliary benefits other than reducing particulate matter episodes. The amount of road dust generated will be the same, and it will ultimately be released to the atmosphere (at lower concentration) or hydrosphere. To conclude, our assessment suggests that increasing aggregate hardness is a good secondary option in a cold climate, after the traffic levers are applied, especially if such materials can be supplied locally.

\section{Conclusions}

With climate change, many regions of the world are experiencing warmer winter temperatures and more precipitation in the form of rainfall or rain on snow. Winter climates may transition from subpolar continental, characterized by little precipitation (that nearly always falls as snow) and low relative humidity, to subpolar oceanic with frequent, light, year-round precipitation, and a narrow temperature band. This study highlights that such changes, specifically more frequent rainfall, higher relative humidity, and higher precipitation intensity in winter, may on one hand reduce winter average $\mathrm{PM}_{10}$ concentrations; on the other hand, a maritime winter climate may promote air pollution episodes and more loading of microplastics to terrestrial and aquatic systems. Moreover, 
the indirect effect of frequent precipitation and fluctuating air temperature around the freezing point is ice formation, which calls for more winter management that generates more dust. The Icelandic experience is that it also prompts the usage of studded tires, even though local authorities regularly remind the population that the majority of the trips are conducted within the urban area where slippery conditions can be managed with plowing and salting. Short-term mitigation on grey days can alleviate air pollution episodes, but not the pollutant loading to waterways and concern of microplastics pollution entering the food chain. The strongest mitigation levers are to reduce the studded tire share and traffic volume, both of which take years to reverse unless strong measures are employed. Pairing restrictions of studded tires use with traffic speed reductions may both help with source reduction, and eliminate the competitive advantage of the personal vehicle being the fastest mean of transport. Last, electrification of the car fleet is no silver bullet in achieving a sustainable road system, as they contribute to road wear.

Author Contributions: Conceptualization and methodology, H.Ó.A., T.T., and S.E.; software, B.C.B., and T.T.; formal analysis, B.C.B.; data curation, B.C.B. and H.Ó.A.; writing-original draft preparation, B.C.B.; writing—review and editing, H.Ó.A., T.T., and S.E.; visualization, B.C.B.; supervision, project administration, funding acquisition, H.Ó.A. All authors have read and agreed to the published version of the manuscript.

Funding: This research was funded by the Icelandic Road and Coastal Administration Research Fund (Icelandic: Rannsóknasjóður Vegagerðarinnar; Grant nr. 1800-678).

Institutional Review Board Statement: Not applicable.

Informed Consent Statement: Not applicable.

Data Availability Statement: Model parameters and input data are available at https:/ / tinyurl.com/ 3stjdnpe and https:/ / tinyurl.com/22t5xshf.

Acknowledgments: Funding: data and expert knowledge from the Icelandic Road and Coastal Administration is greatly appreciated. Efla Consulting Engineers, Samrás ehf, the Environment Agency of Iceland and the Icelandic Meteorological Office are thanked for their help with data acquisition and interpretation. Assistance with the NORTRIP model is acknowledged.

Conflicts of Interest: The authors declare no conflict of interest. The funders had no role in the design of the study; in the collection, analyses, or interpretation of data; in the writing of the manuscript; or in the decision to publish the results.

\section{References}

1. United Nations Department of Economic and Social Affairs Sustainable Development. Available online: https://sdgs.un.org/ goals / goal11 (accessed on 1 February 2021).

2. Segersson, D.; Eneroth, K.; Gidhagen, L.; Johansson, C.; Omstedt, G.; Nylén, A.E.; Forsberg, B. Health impact of PM10, PM2.5 and black carbon exposure due to different source sectors in Stockholm, Gothenburg and Umea, Sweden. Int. J. Environ. Res. Public Health 2017, 14, 742. [CrossRef] [PubMed]

3. Thorpe, A.J.; Harrison, R.M.; Boulter, P.G.; McCrae, I.S. Estimation of particle resuspension source strength on a major London Road. Atmos. Environ. 2007, 41, 8007-8020. [CrossRef]

4. Johansson, C.; Norman, M.; Gidhagen, L. Spatial \& temporal variations of PM10 and particle number concentrations in urban air. Environ. Monit. Assess. 2007, 127, 477-487. [CrossRef] [PubMed]

5. Norman, M.; Johansson, C. Studies of some measures to reduce road dust emissions from paved roads in Scandinavia. Atmos. Environ. 2006, 40, 6154-6164. [CrossRef]

6. Omstedt, G.; Bringfelt, B.; Johansson, C. A model for vehicle-induced non-tailpipe emissions of particles along Swedish roads. Atmos. Environ. 2005, 39, 6088-6097. [CrossRef]

7. Laakso, L.; Hussein, T.; Aarnio, P.; Komppula, M.; Hiltunen, V.; Viisanen, Y.; Kulmala, M. Diurnal and annual characteristics of particle mass and number concentrations in urban, rural and Arctic environments in Finland. Atmos. Environ. 2003, 37, 2629-2641. [CrossRef]

8. Etyemezian, V.; Kuhns, H.; Gillies, J.; Chow, J.; Hendrickson, K.; McGown, M.; Pitchford, M. Vehicle-based road dust emission measurement (III): Effect of speed, traffic volume, location, and season on PM10 road dust emissions in the Treasure Valley, ID. Atmos. Environ. 2003, 37, 4583-4593. [CrossRef] 
9. Järlskog, I.; Strömvall, A.M.; Magnusson, K.; Gustafsson, M.; Polukarova, M.; Galfi, H.; Aronsson, M.; Andersson-Sköld, Y. Occurrence of tire and bitumen wear microplastics on urban streets and in sweepsand and washwater. Sci. Total Environ. 2020, 729, 138950. [CrossRef]

10. Vogelsang, C.; Lusher, A.L.; Dadkhah, M.E.; Sundvor, I.; Umar, M.; Ranneklev, S.B.; Eidsvoll, D.; Meland, S. Microplastics in Road Dust_Characteristics, Pathways and Measures; Norwegian Institute for Water Research (NIVA): Oslo, Norway, 2019.

11. Sommer, F.; Dietze, V.; Baum, A.; Sauer, J.; Gilge, S.; Maschowski, C.; Gieré, R. Tire abrasion as a major source of microplastics in the environment. Aerosol Air Qual. Res. 2018, 18, 2014-2028. [CrossRef]

12. Hann, S.; Sherrington, C.; Jamieson, O.; Hickman, M.; Kershaw, P.; Bapasola, A.; Cole, G. Investigating Options for Reducing Releases in the Aquatic Environment of Microplastics Emitted by (but Not Intentionally Added in) Products; Eunomia Research and Consluting: Bristol, UK, 2018.

13. Kole, J.P.; Löhr, A.J.; van Belleghem, F.G.A.J.; Ragas, A.M.J. Wear and tear of tyres: A stealthy source of microplastics in the environment. Int. J. Environ. Res. Public Health 2017, 14, 1265. [CrossRef]

14. Evangeliou, N.; Grythe, H.; Klimont, Z.; Heyes, C.; Eckhardt, S.; Lopez-Aparicio, S.; Stohl, A. Atmospheric transport is a major pathway of microplastics to remote regions. Nat. Commun. 2020, 11, 3381. [CrossRef]

15. Freitas, E.; Pereira, P.; de Picado-Santos, L.; Santos, A. Traffic Noise Changes due to Water on Porous and Dense Asphalt Surfaces. Road Mater. Pavement Des. 2009, 10, 587-607. [CrossRef]

16. Llopis-Castelló, D.; García-Segura, T.; Montalbán-Domingo, L.; Sanz-Benlloch, A.; Pellicer, E. Influence of pavement structure, traffic, and weather on urban flexible pavement deterioration. Sustainability 2020, 12, 9717. [CrossRef]

17. Hänninen, O.; Knol, A.B.; Jantunen, M.; Lim, T.A.; Conrad, A.; Rappolder, M.; Carrer, P.; Fanetti, A.C.; Kim, R.; Buekers, J.; et al. Environmental burden of disease in Europe: Assessing nine risk factors in six countries. Environ. Health Perspect. 2014, 122, 439-446. [CrossRef] [PubMed]

18. Sharma, S.; Chatterjee, S. Microplastic pollution, a threat to marine ecosystem and human health: A short review. Environ. Sci. Pollut. Res. 2017, 24, 21530-21547. [CrossRef] [PubMed]

19. Akin, M.; Fay, L.; Shi, X. Friction and Snow-Pavement Bond after Salting and Plowing Permeable Friction Surfaces. Transp. Res. Rec. 2020, 2674, 794-805. [CrossRef]

20. Gustafsson, M.; Blomqvist, G.; Gudmundsson, A.; Dahl, A.; Swietlicki, E.; Bohgard, M.; Lindbom, J.; Ljungman, A. Properties and toxicological effects of particles from the interaction between tyres, road pavement and winter traction material. Sci. Total Environ. 2008, 393, 226-240. [CrossRef] [PubMed]

21. Norman, M.; Sundvor, I.; Denby, B.R.; Johansson, C.; Gustafsson, M.; Blomqvist, G.; Janhäll, S. Modelling road dust emission abatement measures using the NORTRIP model: Vehicle speed and studded tyre reduction. Atmos. Environ. 2016, 134, 96-108. [CrossRef]

22. Lundberg, J.; Janhäll, S.; Gustafsson, M.; Erlingsson, S. Calibration of the Swedish studded tyre abrasion wear prediction model with implication for the NORTRIP road dust emission model. Int. J. Pavement Eng. 2019, 22, 432-446. [CrossRef]

23. Denby, B.R.; Sundvor, I.; Johansson, C.; Pirjola, L.; Ketzel, M.; Norman, M.; Kupiainen, K.; Gustafsson, M.; Blomqvist, G.; Omstedt, G. A coupled road dust and surface moisture model to predict non-exhaust road traffic induced particle emissions (NORTRIP). Part 1: Road dust loading and suspension modelling. Atmos. Environ. 2013, 77, 283-300. [CrossRef]

24. Denby, B.R.; Sundvor, I.; Johansson, C.; Pirjola, L.; Ketzel, M.; Norman, M.; Kupiainen, K.; Gustafsson, M.; Blomqvist, G.; Kauhaniemi, M.; et al. A coupled road dust and surface moisture model to predict non-exhaust road traffic induced particle emissions (NORTRIP). Part 2: Surface moisture and salt impact modelling. Atmos. Environ. 2013, 81, 485-503. [CrossRef]

25. Ketzel, M.; Omstedt, G.; Johansson, C.; Düring, I.; Pohjola, M.; Oettl, D.; Gidhagen, L.; Wåhlin, P.; Lohmeyer, A.; Haakana, M.; et al. Estimation and validation of PM2.5/PM10 exhaust and non-exhaust emission factors for practical street pollution modelling. Atmos. Environ. 2007, 41, 9370-9385. [CrossRef]

26. Gustafsson, M.; Blomqvist, G.; Järlskog, I.; Lundberg, J.; Janhäll, S.; Elmgren, M.; Johansson, C.; Norman, M.; Silvergren, S. Road dust load dynamics and influencing factors for six winter seasons in Stockholm, Sweden. Atmos. Environ. X 2019, $2,100014$. [CrossRef]

27. Tomassetti, L.; Torre, M.; Tratzi, P.; Paolini, V.; Rizza, V.; Segreto, M.; Petracchini, F. Evaluation of air quality and mobility policies in 14 large Italian cities from 2006 to 2016. J. Environ. Sci. Health Part A Toxic/Hazard. Subst. Environ. Eng. 2020, 55, 886-902. [CrossRef]

28. Aygün, O.; Kinnard, C.; Campeau, S. Impacts of climate change on the hydrology of northern midlatitude cold regions. Prog. Phys. Geogr. Earth Environ. 2020, 44, 338-375. [CrossRef]

29. Andradóttir, H.Ó.; Arnardóttir, A.R.; Zaqout, T. Rain on snow induced urban floods in cold maritime climate: Risk, indicators and trends. Hydrol. Process. 2021. [CrossRef]

30. Skúladóttir, B.; Thorlacius, A.; Larssen, S.; Bjarnason, G.G.; Pórdarson, H. Method for Determining the Composition of Airborne Particle Pollution; Nordtest: Espoo, Finland, 2003; p. 30.

31. Höskuldsson, P.; Thorlacius, A. Uppruni Svifryks i Reykjavik; EFLA Consulting Engineers: Reykjavík, Iceland, $2017 ;$ p. 17.

32. Sigurðsson, V.; Halldórsson, P. Örplast í Hafinu við Ísland: Helstu Uppsprettur, Magn og Farvegir í Umhverfinu; Biopol and Náttúrufræðistofa Norðurlands Vestra: Sauðárkróki, Iceland, 2019.

33. Butwin, M.K.; von Löwis, S.; Pfeffer, M.A.; Thorsteinsson, T. The effects of volcanic eruptions on the frequency of particulate matter suspension events in Iceland. J. Aerosol Sci. 2019, 128, 99-113. [CrossRef] 
34. Thorsteinsson, T.; Jóhannsson, T.; Stohl, A.; Kristiansen, N.I. High levels of particulate matter in Iceland due to direct ash emissions by the Eyjafjallajökull eruption and resuspension of deposited ash. J. Geophys. Res. Solid Earth 2012, 117, 1-9. [CrossRef]

35. Thorsteinsson, T.; Gísladóttir, G.; Bullard, J.; McTainsh, G. Dust storm contributions to airborne particulate matter in Reykjavík, Iceland. Atmos. Environ. 2011, 45, 5924-5933. [CrossRef]

36. Andradottir, H.O.; Thorsteinsson, T. Repeated extreme particulate matter episodes due to fireworks in Iceland and stakeholders response. J. Clean. Prod. 2019, 236, 117511. [CrossRef]

37. Environment Agency of Iceland. Hourly Air Quality Data at Grensás Urban Traffic Station 2017-2018. Unpublished Work. 2018.

38. EFLA Consulting Engineers. Studded Tires Counts in Reykjavík City 2000 to 2018. Unpublished Work.

39. Denby, B.R.; Sundvor, I. NORTRIP Model Development and Documentation: NOn-Exhaust Road TRaffic Induced Particle Emission Modelling; NILU: Oslo, Norway, 2012.

40. Denby, B.R.; Ketzel, M.; Ellermann, T.; Stojiljkovic, A.; Kupiainen, K.; Niemi, J.V.; Norman, M.; Johansson, C.; Gustafsson, M.; Blomqvist, G.; et al. Road salt emissions: A comparison of measurements and modelling using the NORTRIP road dust emission model. Atmos. Environ. 2016, 141, 508-522. [CrossRef]

41. Icelandic Road \& Coastal Administration. Traffic Counts, Meteorology and Winter Management at Kauptún 2017-2019. Unpublished Work. 2019.

42. Icelandic Meteorological Office. Radiation and Precipitation at Reykjavík Station nr. 1. Unpublished Work. 2019.

43. Feiccabrino, J.; Graff, W.; Lundberg, A.; Sandström, N.; Gustafsson, D. Meteorological knowledge useful for the improvement of snow rain separation in surface based models. Hydrology 2015, 2, 266-288. [CrossRef]

44. Jensen, S.S.; Ketzel, M.; Brandt, J.; Becker, T.; Plejdrup, M.; Winther, M.; Ellermann, T.; Christensen, J.H.; Nielsen, O.-K.; Hertel, O. Air Quality at Your Street-Public Digital Map of Air Quality in Denmark. In Proceedings of the Sixth Scientific Meeting EuNetAir; Academy of Sciences: Prague, Czech Republic, 2016; pp. 14-17. [CrossRef]

45. Jacobson, T.; Wågberg, L.-G. Utveckling och Uppgradering av Prognosmodell för Beläggningsslitage från Dubbade däck samt en Kunskapsöversikt över Inverkande Faktorer; VTI: Linköping, Sweden, 2007.

46. Barr, B.C. Processes and Modeling of Non-Exhaust Vehicular Emissions in the Icelandic Capital Region. Master's Thesis, University of Iceland, Reykjavík, Iceland, 2020.

47. European Environmental Agency. Air Quality in Europe-2020 Report; EEA Report No 9/2020; European Environmental Agency: København, Denmark, 2020. [CrossRef]

48. World Health Organization. Air Quality Guidelines Global Update 2005. Particulate Matter, Ozone, Nitrogen Dioxide and Sulfur Dioxide; WHO: Geneva, Switzerland, 2005; ISBN 9289021926.

49. Ud Din, I.M.; Mir, M.S.; Farooq, M.A. Effect of Freeze-Thaw Cycles on the Properties of Asphalt Pavements in Cold Regions: A Review. Transp. Res. Procedia 2020, 48, 3634-3641. [CrossRef]

50. Pascale, A.; Fernandes, P.; Guarnaccia, C.; Coelho, M.C. A study on vehicle Noise Emission Modelling: Correlation with air pollutant emissions, impact of kinematic variables and critical hotspots. Sci. Total Environ. 2021, 787, 147647. [CrossRef]

51. Temporelli, A.; Carvalho, M.L.; Girardi, P. Life Cycle Assessment of Electric Vehicle Batteries: An Overview of Recent Literature. Energies 2020, 13, 2864. [CrossRef]

52. Timmers, V.R.J.H.; Achten, P.A.J. Non-exhaust PM emissions from electric vehicles. Atmos. Environ. 2016, 134, 10-17. [CrossRef]

53. Milovanoff, A.; Posen, I.D.; MacLean, H.L. Electrification of light-duty vehicle fleet alone will not meet mitigation targets. Nat. Clim. Chang. 2020, 10, 1102-1107. [CrossRef]

54. Lundberg, J.; Gustafsson, M.; Janhäll, S.; Eriksson, O.; Blomqvist, G.; Erlingsson, S. Temporal Variation of Road Dust Load and Its Size Distribution-A Comparative Study of a Porous and a Dense Pavement. Water. Air. Soil Pollut. 2020, 231, 561. [CrossRef] 